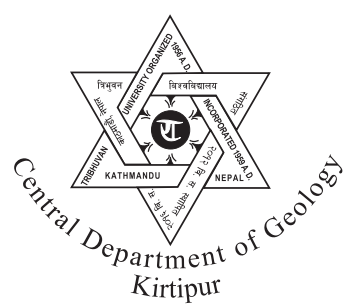

\title{
Petrographic records of two metamorphic events in the Lesser Himalayan metabasites, Modi Khola section, central Nepal
}

\author{
Lalu Paudel
}

Central Department of Geology, Tribhuvan University, Kirtipur, Kathmandu, Nepal

\begin{abstract}
Metabasites of the Lesser Himalaya along the Modi Khola valley in central Nepal are the supracrustal dikes and sills of basic igneous rocks emplaced in the clastic sediments and later metamorphosed together with the host rocks. They contain almost a constant metamorphic mineral assemblage of $\mathrm{Ca}$-amphiboles+plagioclase+biotite+quartz \pm epidote \pm chlorite $+(\mathrm{Fe}-\mathrm{Ti}$ oxides $)$. Amphiboles occur in the form of porphyroblast and recrystallized matrix. The porphyroblasts are zoned with actinolitic cores and hornblende rims. The recrystallized matrix ranges in composition from actinolite in chlorite zone to hornblende in biotite and garnet zones. The cores of porphyroblasts are pre-kinematic and were probably formed prior to the Tertiary Himalayan orogeny. The rims of porphyroblasts and matrix amphiboles are syn-kynematic and were formed during the Upper Main Central Thrust activity in the Tertiary. The systematic changes in amphibole compositions as well as textural characteristics of metabasites are in good agreement with the classical concept of increasing metamorphic grade and intensity of deformation structurally upwards towards the Upper Main Central Thrust in the Lesser Himalaya.
\end{abstract}

\section{INTRODUCTION}

There are several controversial issues related to metamorphic evolution of the Lesser Himalaya in Nepal. Some of the important issues are polymetamorphism, pre-collisional and postcollisional thermal events and the nature and origin of the inverted metamorphism. This controversy is mainly because of lower-grade metamorphic condition, lack of appropriate mineral assemblages, and relatively fine-grained nature of the metapelitic rocks in the Lesser Himalaya. Metabasites intercalated within metasediments are common in the northern part of the Lesser Himalaya. Unlike extensive studies on metapelites of the Lesser Himalaya and the MCT (Main Central Thrust) zone (see Bollinger et al. 2004; Catlos et al. 2001; Guillot 1999), no studies have been made on those metabasites. Metabasites are

*Corresponding author:

E-mail address: lalupaude1671@yahoo.com mineralogically more sensitive to variation in pressure and temperature and may record metamorphic information which is not found in equivalent metasediments (Miyashiro 1973). Phase relationships in metabasites are dependent on metamorphic grade (Graham 1974; Rasse 1974; Brown 1977; Holland and Richardson 1979; Liard and Albee 1981), and amphiboles in metabasites have high potential for pressure-temperature path reconstruction (Blundy and Holland 1990; Triboulet et al. 1992; Zenk and Schulz 2004). The present work is aimed at studying the metabasites from the Lesser Himalaya in the Modi Khola section, central Nepal (Fig. 1) to provide complementary insights into the nature and history of metamorphism in the Lesser Himalaya.

\section{GEOLOGICAL SETTING AND OCCURRENCE OF METABASITES}

Central Nepal can be divided into four tectonic 


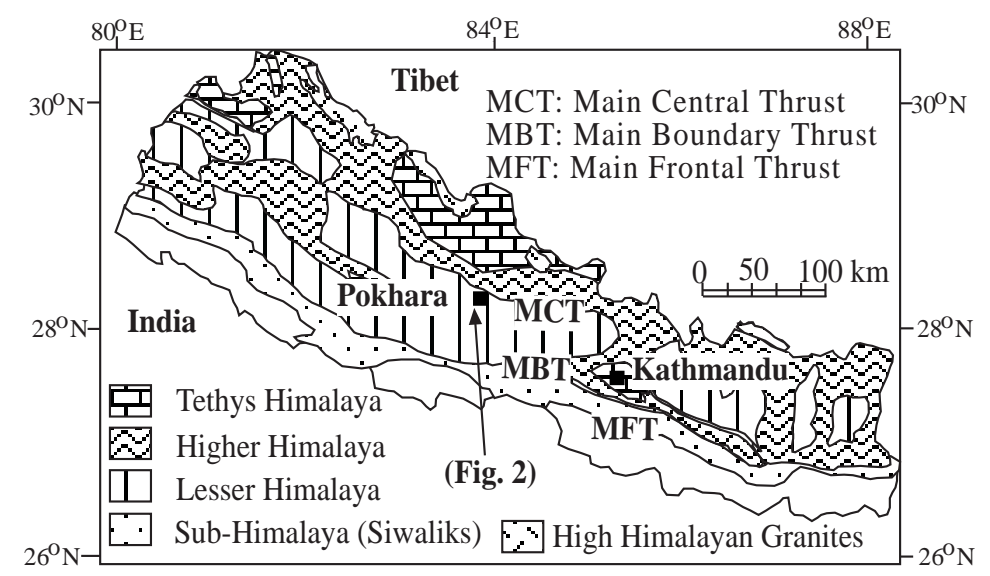

Fig. 1 Generalized tectonic map of the Nepal Himalaya showing the location of the present study area (modified after Upreti 1999) zones; from south to north, the Sub-Himalaya, the Lesser Himalaya (LH), the Higher Himalaya (HH) and the Tethys Himalaya (Fig. 1) (Gansser 1964). The LH is a fold-and-thrust belt bounded by the Main Boundary Thrust (MBT) in the south and by the Upper MCT in the north. The detailed tectonostratigraphy of the LH in the study area is found elsewhere (Sakai 1985; Dhital et al. 1998; Paudel and Arita 2000). Only a brief geological outline of the LH north of the Bari Gad-Kali Gandaki Fault, referred as the inner LH (Arita et al. 1982), is given here. The inner LH comprises low- to medium-grade metasedimentary rocks of the Nawakot Complex ranging in age from the late Precambrian to early Paleozoic (Stöcklin 1980) and is further divided into three tectonic zones from south to north, viz., the Thrust Sheet I (TS I), Thrust Sheet II (TS II), and the MCT zone (Fig. 2). The Phalebas Thrust (PT) separates TS I from II, and the Lower MCT separates the TS II from the MCT zone. The LH is overthrust by the $\mathrm{HH}$ along the Upper MCT.

The TS I comprises the middle part of the Nawakot Complex viz. the Nourpul Formation (phyllite and quartzite), Dhading Dolomite (dolomite and slate), and the Benighat Slate (slate and limestone). The TS II consists of the Kunchha Formation (phyllite, metasandstone), Fagfog Quartzite (quartzite, phyllite) and the Dandagaon Phyllite (phyllite, metasandstone) belonging to the lower part of the Nawakot Complex. The MCT zone comprises intercalation of garnetiferous pelitic, psammitic and carbonaceous schists, and mylonitic augen gneisses. The MCT zone here includes only the footwall rocks of the Upper
MCT whose protoliths were of the LH affinity, and should not be confused with others' definition from structural point of view that includes also a part of the hanging wall (the lower part of the $\mathrm{HH}$ ) into the MCT zone.

Mainly two prominent foliations can be observed in the metasediments of the inner belt of the LH (Pêcher 1977; Paudel and Arita 2000). The older one is a bedding-parallel foliation $\left(\mathrm{S}_{1}=\mathrm{S}_{0}\right)$ predating the Upper MCT activity and can be observed in the verylow grade rocks of the TS II. The younger one $\left(\mathrm{S}_{2}\right)$ is either a crenulation cleavage (in TS II) or a shear foliation (in the MCT zone). The $S_{1}$ cannot be recognized in the metabasites, but $S_{2}$ is quite prominent. Microstructural features such as the parallelism of $\mathrm{S}_{2}$ with the Upper MCT and confinement of stretching/mineral lineations on $\mathrm{S}_{2}$ indicate that the $S_{2}$ was syntectonic to the Upper MCT activity (Bouchez and Pêcher 1981; Brunel 1986).

Sheet-like bodies of metabasites are found intercalated within the metasediments of the lower part of the Nawakot Complex. They are abundant in the TS II and the MCT zone (Fig. 2). In some places they range in thickness from a few meters to tens of meters and extend hundreds of meters along the strike. But in other places, they are thin (less than a meter) and pinch-out within a few meters. They are green to dark green, very hard and massive, medium- to coarse-grained, often foliated and deformed along with the associated metasediments. Foliation is strongly developed in relatively thin and fine-grained bodies compared to that in relatively thick and coarse- 
(a)

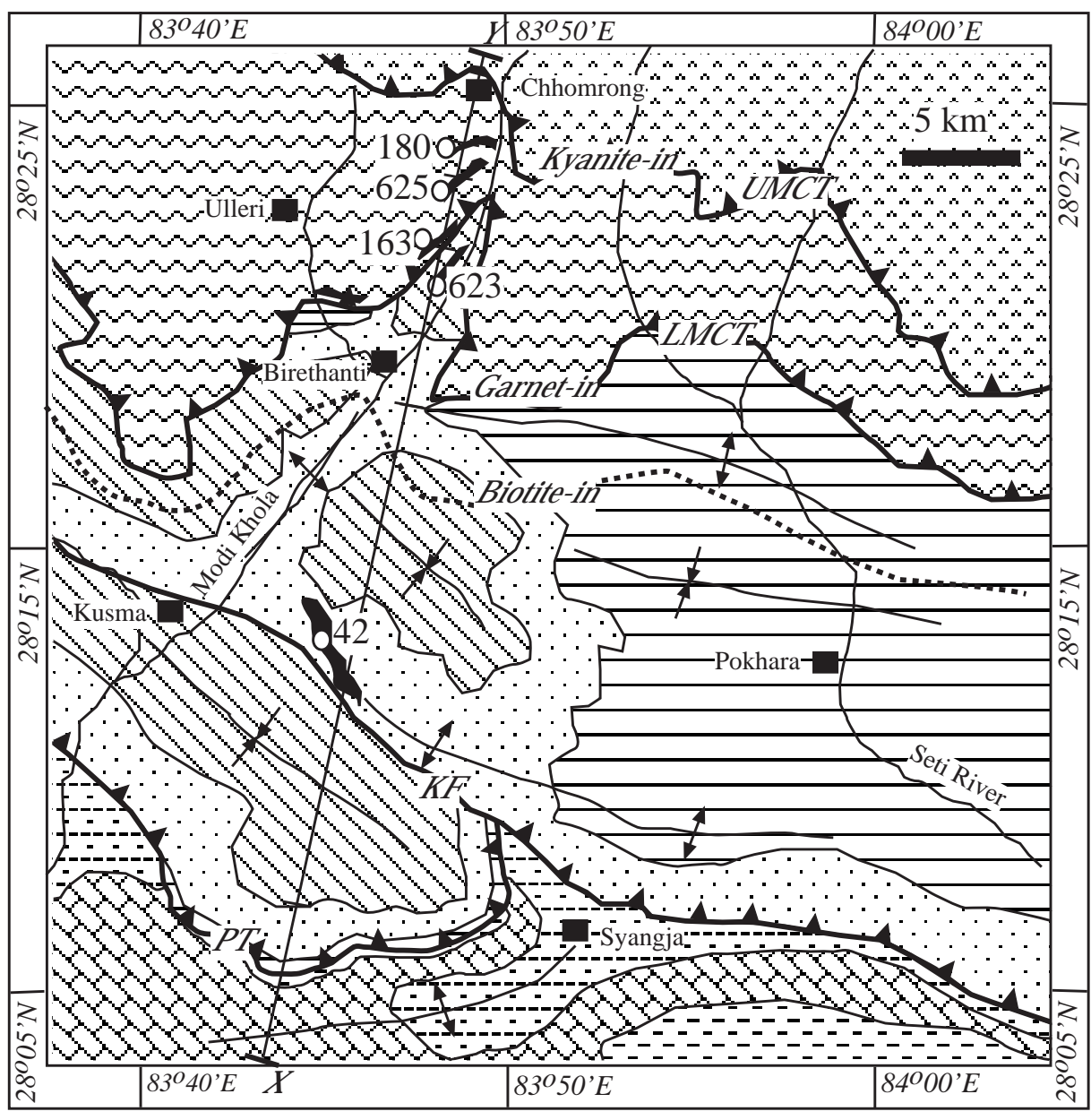

\section{Higher Himalaya

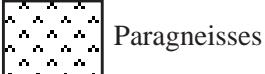 \\ Lesser Himalaya}

MCT zone

Pelitic and psammitic

schits, augen gneiss,

$\sim$ marble

TS I and TS II

:-:--- Benighat Slate

Dhading Dolomite

2. (dolomite, slate)

Nourpul Formation

- (phyllite, quartzite)

Dandagaon Phyllite (phyllite, quartzite)

$\because \therefore$ Fagfog Quartzite

$\therefore \therefore$ (quartzite, phyllite)

Kunchha Formation (phyllite, metasandstone)

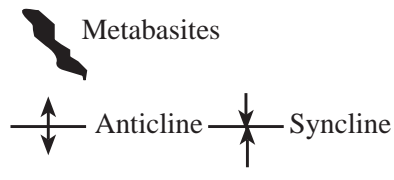

0163 Sample site and number

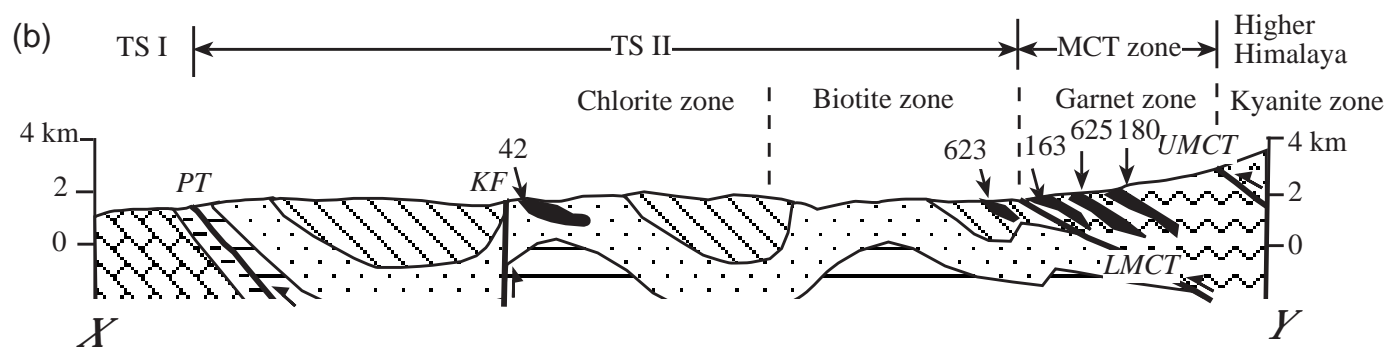

Fig. 2 (a) Geological map of the Pokhara-Kusma area (modified after Paudel and Arita 2000). UMCT: Upper Main Central Thrust, LMCT: Lower Main Central Thrust, KF: Kusma Fault, PT: Phalebas Thrust, TS I: Thrust sheet I, TS II: Thrust sheet II, MCT zone: Main Central Thrust zone. X-Y: line of cross-section. Biotite isograd is shown by dotted line. Garnet and kyanite isograds coincide with the Lower and Upper MCTs, respectively. (b) Geological cross-section along X-Y

grained bodies. The contact with the country rocks is often sharp and concordant. Similar rocks in the Indian LH are dated at $1907 \pm 91$ Ma based on whole rock Rb-
Sr isochron method (Ahmad et al. 1999). The metabasites are the basic lava flows or supracrustal dikes and sills emplaced into the clastic sediments in the Precambrian. 


\section{PETROGRAPHY OF METABASITES}

Metabasite samples were collected from 5 sites along the Modi Khola valley. One sample belongs to chlorite zone (No. 42), one belongs to biotite zone (No. 623) and three belong to garnet zone (Nos. 163, 625 , and 180). Thin sections were prepared along the stretching lineation and perpendicular to $S_{2}$ foliation planes, and microstructural and mineralogical studies were carried out on them.

\section{Chlorite zone}

\section{Sample No. 42}

This sample comes from a metabasic sill-like body within the Fagfog Quartzite in the TS II. The recrystallized matrix contains the assemblage actinolite+chlorite+epidote+albite+quartz with some opaques (ilmenite, magnetitie) as accessories (Fig. 3a). Needle-shaped actinolite and chlorite define the $\mathrm{S}_{2}$ foliation. Relic phenocrysts of plagioclase (albite) are subhedral to anhedral and range in size from 0.5 to $3 \mathrm{~mm}$. They are characterized by clear polysynthetic twinning and are frequently sericitized. Epidote and quartz occur as fine-grained aggregates. Porphyroblastic amphiboles do not exist in this sample.

\section{Biotite zone}

\section{Sample No. 623}

This sample is from the northern part of the TS II below the Lower MCT. The original igneous textures are partly preserved in this sample. It contains the assemblage amphiboles+biotite+chlorite+epidote+albite+quartz with titanite and magnetite as accessories. It is characterized by the occurrences of coarse-grained porphyroblast and fine-grained matrix of amphiboles. Amphiboles cover about $80 \%$ in modal abundance. In the less deformed parts, it shows apparent sub-ophitic texture with laths of plagioclase. Some amphibole porphyroblasts have prismatic shape, and probably they are pseudomorphs after clinopyroxene (Fig. 3b). Porphyroblastic amphiboles (mainly actinolite) are sheared and fractured, and show asymmetric pressure shadows. Newly grown matrix amphiboles can be seen in the pressure shadows and also along the $S_{2}$ shear foliation. The asymmetric pressure shadows show top-to-the-south sense of shear in the LH.

\section{Garnet zone}

With increasing metamorphic grade into the garnet zone, blue-green hornblende and actinolite occur together. Actinolite cores are invariably surrounded by hornblende rims in simple zonal arrangement. Plagioclase is plastically deformed and recrytallized, and elongated along the $S_{2}$ foliation. They lack polysynthetic twinning. Modal percentage and grain size of amphiboles and biotite increases and that of chlorite decreases compared to those in the biotite zone. Both porphyroblast and matrix amphiboles and plagioclase are strongly elongated and oriented parallel to the MCT shear zone. Detailed petrography of each sample is given below.

\section{Sample No. 163}

This sample is from a coarse-grained sill-like body in the lower part of the MCT zone. It is porphyritic, coarse-grained (amphiboles $>1.0$ $\mathrm{mm}$ ) and has the assemblage amphiboles+plagioclase+biotite+quartz+titani te + magnetite \pm epidote \pm chlorite. Amphiboles become more dark-green in color instead of light pale-green amphiboles in the chlorite and biotite zone samples. Decrease or absence of epidote and chlorite indicates an increase in metamorphic grade. Large porphyroblasts of actinolite $(>2 \mathrm{~cm})$ are commonly sheared and broken apart by $\mathrm{S}_{2}$ shear planes (Fig. $3 c)$. Hornblende commonly occurs as patches within the sheared porphyroblasts, as overgrown rims of porphyroblasts and as recrystallized grains in matrix (Figs. 3c and d). Late stage alteration along cracks

Fig. 3. Photomicrographs of metabasites. (a) Sample No. 42 from the chlorite zone is dominated by porphyroclastic (igneous relics) plagioclase, chlorite and quartz. Fine-grained recrastallized actinolite occurs only along $S_{2}$ foliation. (b) Sample No. 623 from biotite zone contains sheared actinolite porphyroblast with asymmetric pressure shadows. Dark-green hornblende is present as overgrown rim of porphyroblast in the pressure shadows and matrix along $\mathrm{S}_{2}$ foliation. Well-preserved prismatic shape of the porphyroblast indicates that the actinolite is a pseudomorph after clinopyroxene. (c) Sample No. 163 from the lower part of the garnet zone (MCT zone) contains large, highly sheared porphyroblasts of actinolite. Patchy intergrowth of blue-green hornblende (Hbl) and actinolite (Act) within amphibole porphyroblast is common. Needle-shaped synkinematic hornblende are strongly oriented parallel to the shear plane $\left(\mathrm{S}_{2}\right)$. (d) Some porphyroblasts in Sample No. 163 show acicular overgrowth of hornblende along $\mathrm{S}_{2}$. (e) Sample No. 625 from 
(a) Chlorite zone

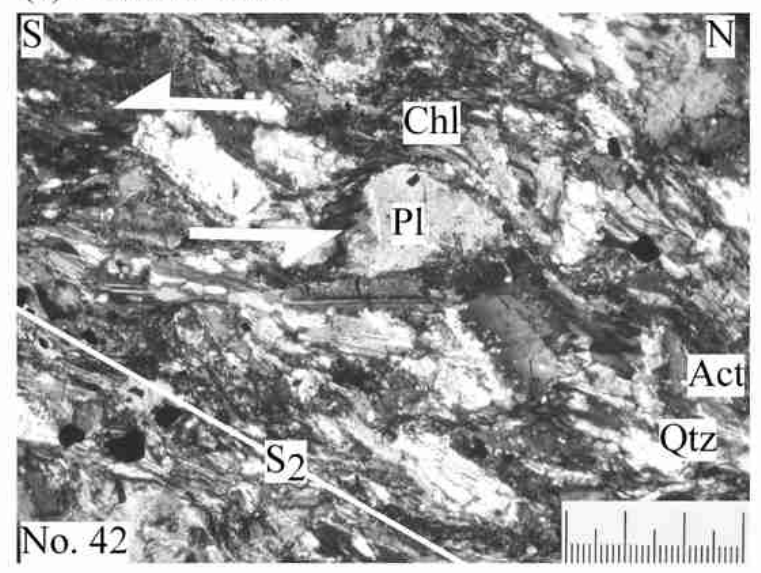

(c) Garnet zone

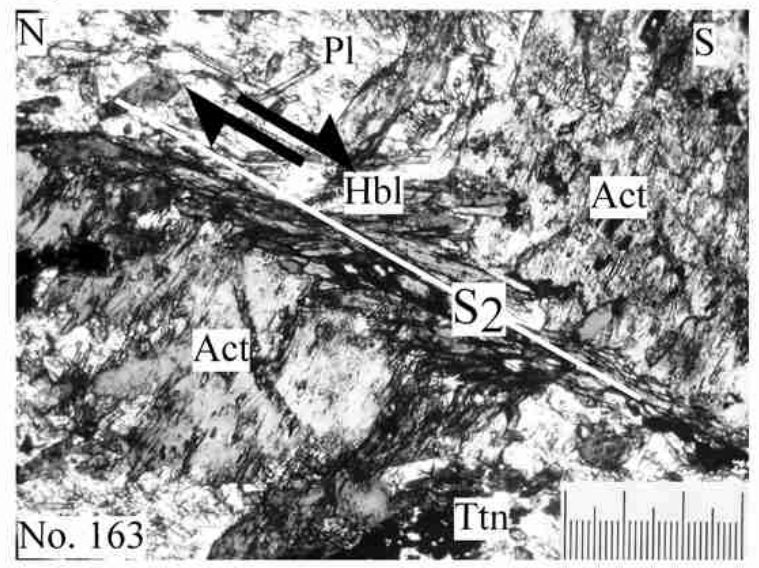

(e) Garnet zone

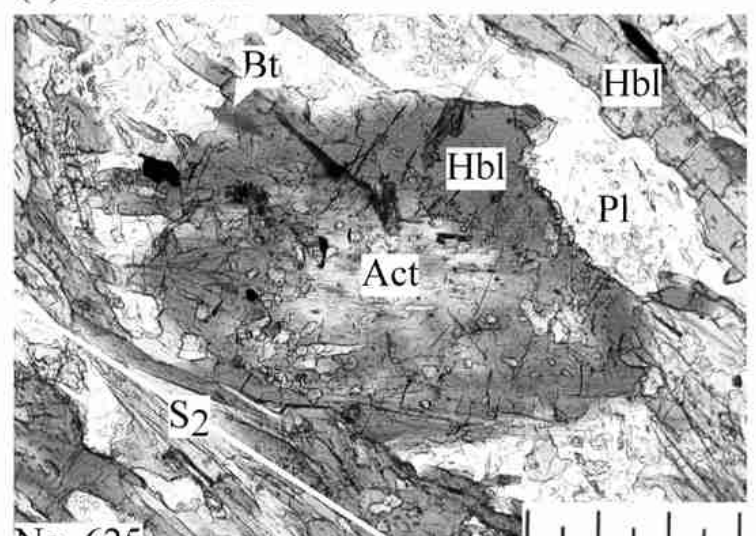

(b) Biotite zone

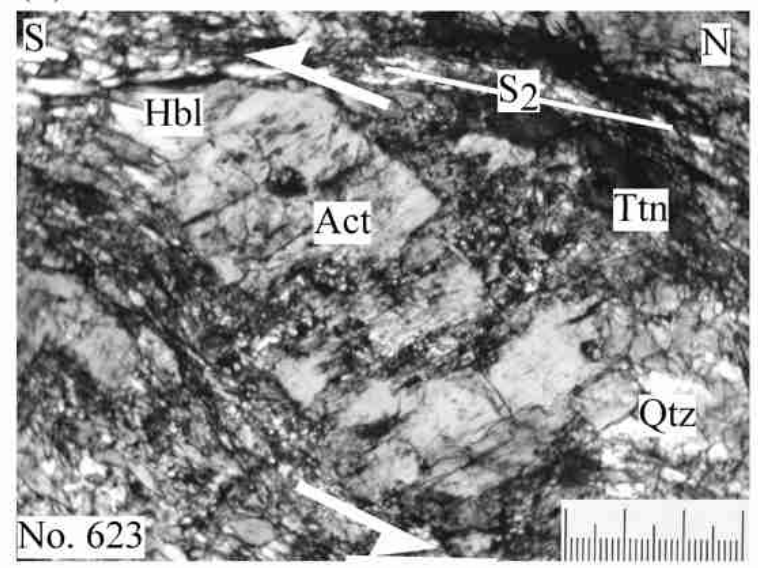

(d) Garnet zone

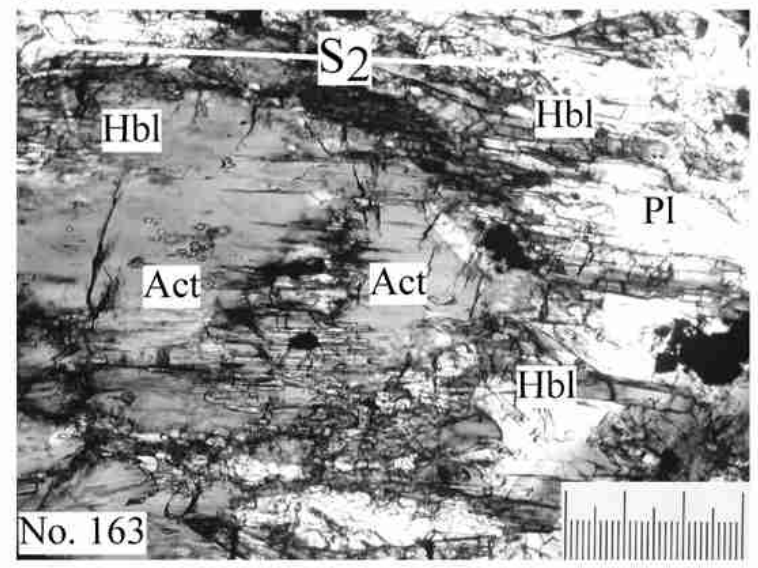

(f) Garnet zone

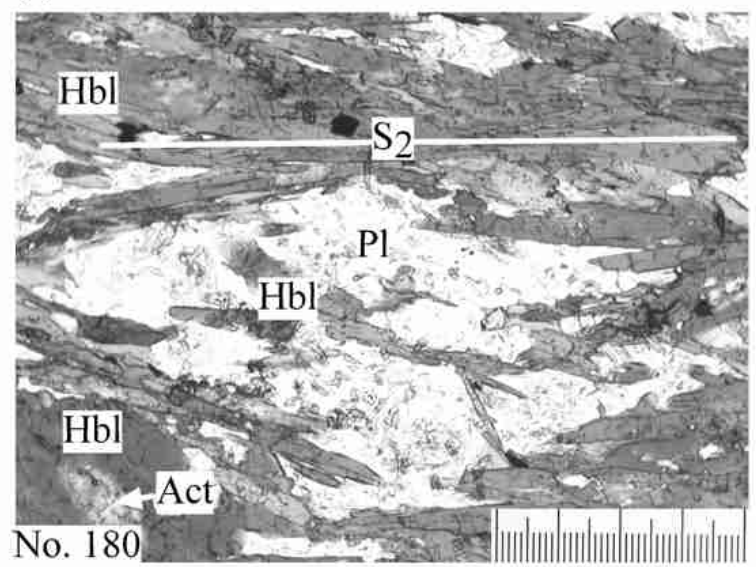

middle part of the garnet zone contains zoned porphyroblast with actinolite cores and hornblende rims. Overgrowth of rims across the foliation is observed in some porphyroblasts. Matrix is relatively coarse-grained and strongly oriented parallel to the $S_{2}$ shear foliation. (f) Sample No. 180 from the middle part of the garnet zone (MCT zone) is highly sheared compared to the other samples. Amphibole porphyroblasts are slightly zoned with patches of actinolite in the cores and hornblende in the rim (bottom left corner). Plagioclase porphyroblast show pokilitic texture with inclusions of recrystallized hornblende (centre). Act: Actinolite, Hbl: Hornblende, Chl: Chlorite, Bt: Biotite, Pl: Plagioclase, Qtz: Quartz, Ttn: Titanite. $S_{2}$ : Shear foliation parallel to the Upper MCT. 1 small division of scale is $0.01 \mathrm{~mm}$ 
and cleavages is common. Syn-kinematic needleshaped amphibole grains in matrix are oriented parallel to the $\mathrm{S}_{2}$ shear plane (Fig. 3c). Plagioclase is much more deformed and has sutured grain boundary with the quartz and amphiboles. They have no twining.

\section{Sample No. 625}

This sample is from the middle part of the MCT zone. It contains the assemblage amphiboles+plagioclase+biotite+quartz+titanite \pm e pidote \pm chlorite. Amphibole is dark-green colored. Modal abundance of amphibole is very high (>80\%). Zoned porphyroblasts with light pale-green actinolite cores and dark-green hornblende rims are abundant in the sample (Fig. 3e). Some grains are strongly elongated parallel to the $S_{2}$ shear foliation. Grain boundaries of the amphibole porphyroblasts are very irregular and slightly resorbed. The porphyroblasts are mostly of poiklitic nature with inclusions of quartz and opaques. Some grains show post-kinematic overgrowth across the foliation (Fig. 3e). The matrix amphibole is coarse-grained $(>0.3 \mathrm{~mm}$ in length) and elongated parallel to the foliation. Epidote and chlorite is present in very minor amount $(<5 \%)$. Plagioclase occurs as inclusion-rich (inclusions of quartz and amphiboles) anhedral grains.

\section{Sample No. 180}

This sample is also from the middle part of the MCT zone, about $500 \mathrm{~m}$ north from No. 625. It contains the assemblage of amphiboles+plagioclase+biotite+quartz+tit anite \pm epidote. Chlorite does not occur and modal abundance of biotite is significantly high in this sample ( $5-10 \%)$. Amphibole grains (both porphyroblasts and matrix) are highly elongated parallel to the $S_{2}$ shear foliation (Fig. 3f). Grain size of amphibole and plagioclase porphyroblasts is smaller compared to that in the samples from the lower part of the MCT zone probably due to strong shearing and recrystallization. The porphyroblastic amphiboles are characterized by patchy zoning, irregular grain boundaries, poikilitic texture, and frequent overgrowth across $\mathrm{S}_{2}$. The recrystallized amphibole grains in the matrix are clean and lack any optical zoning. The plagioclase porphyroblasts contain inclusions of needle-shaped amphiboles (Fig. 3f).

The metabasites mineralogy shows overall increase in metamorphic grade and degree of recrystallization towards the north (structurally upwards) in agreements with the northward increasing metamorphism shown by metapelites mineralogy.

\section{DISCUSSION ON TWO METAMORPHIC EVENTS IN THE LESSER HIMALAYA}

The polymetamorphic evolution of the LH has been so far inferred based on the indirect evidence such as (i) discordance of illite crystallinity between the Gondwana and pre-Gondwana sediments (Johnson and Oliver 1990; Paudel and Arita 2000), (ii) bimodal compositions of white micas (Paudel and Arita, 2006) and pre-collisional and post-collisional white mica ages (Oliver et al. 1995). Due to the difficulties in separating detrital white micas from recrystallized ones in clastic metasedimets, the reliability of the above evidences was uncertain. However, the zoned amphiboles in metabasites provide more reliable evidence for the polymetamorphic evolution of the LH. The actinolite-hornblende pairs in metabasites result from multiple stages of mineral growths and incomplete chemical equilibration between cores and rims formed during different metamorphic stages (Graham 1974; Holland and Richardson 1979; Liard and Albee 1981). The porphyroblasts in lower grade

Table 1: Published ${ }^{40} \mathrm{Ar} /{ }^{39} \mathrm{Ar}$ and $\mathrm{K}-\mathrm{Ar}$ cooling ages of amphiboles from the Lesser Himalaya in Nepal

\begin{tabular}{lll}
\hline Sample No. & Age (Ma) & Dist. From the Upper MCT \\
\hline *AP787 & $15.2 \pm 0.2$ & $100 \mathrm{~m}$ \\
*Ap483 & $4.1 \pm 1.3$ & $500 \mathrm{~m}$ \\
*AP842 & $94.8 \pm 0.5$ & $2 \mathrm{~km}$ \\
*AP343 & $24.6 \pm 1.9$ & $2.5 \mathrm{~km}$ \\
**KA713 & $69.4 \pm 2$ & \\
**KA343 & $253 \pm 15$ & \\
**KA345 & $96.5 \pm 5$ & \\
**KA339 & $411 \pm 16$ & \\
**KA341 & $695 \pm 25$ & \\
**FW0022 & $12.5 \pm 0.4$ & \\
\# & $819 \pm 80$ & \\
\hline
\end{tabular}

*Copeland et al. (1991), Lesser Himalaya, Buri Gandaki Valley, ${ }^{40} \mathrm{Ar} /{ }^{39} \mathrm{Ar}$ hornblende ages; $* *$ Krummenacher et al. (1978), Lesser Himalaya, Eastern Nepal, K-Ar hornblende ages; ***Bollinger and Jantos (2006), Lesser Himalaya, Far-western Nepal, ${ }^{40} \mathrm{Ar} /{ }^{39} \mathrm{Ar}$ hornblende ages; \# Krummenacher (1966), Lesser Himalaya, Kali Gandaki Valley, K-Ar hornblende ages 
rocks (biotite zone) are either wrapped up or broken apart by the shear planes (Figs. 3b and c) clearly showing that they are pre-kinematic. They are essentially made up of actinolite. In higher grade rocks (garnet zone), with more prograde recrystallization, the actinolite cores are armored by newly crystallized hornblende/tschermakite (Figs. $6 \mathrm{c}, \mathrm{d}$, and e). The actinolite is preserved as relic core of the porphyroblast.

As the shear foliation $\left(S_{2}\right)$ in the MCT zone is parallel to the Upper MCT, it is clear that the lowgrade metamorphism occurred prior to the thrusting along the Upper MCT. In view of the pre-Tertiary amphibole cooling ages from the Nepal Himalaya (Table 1), it is believed that the LH experienced a thermal event prior to the India-Asia collision in the Tertiary and the pre-kinematic actinolitic amphiboles are the products of pre-Tertiary (pre-Himalayan) thermal event.

The inner LH experienced peak metamorphism (Neohimalayan stage) during the Upper MCT activity. Textural records in amphiboles confirm that the matrix amphiboles related to the peak-metamorphic event grew preferentially along the shear planes parallel to the Upper MCT. Although most of porphyroblasts show preferred overgrowth along the foliation, some porphyroblasts show overgrowth across the shear planes. The above evidences show that the Neohimalayan metamorphism was mainly a synkinematic event, but the high temperature condition lasted for long time allowing post-kineamtic overgrowth of the amphiboles. Parallelism of shear foliations to the Upper MCT, and presence of stretching and mineral lineation indicate that the second metamorphism is undoubtedly related to the movement along the Upper MCT (Le Fort 1975; Arita 1983; Pêcher 1989). The changes in composition of syn-kinematic amphiboles, and textural characteristics mentioned above confirm the classical concept of increasing metamorphic grade northwards (structurally upwards) in the LH. The inverted metamorphism is coeval to the shearing due to the Upper MCT activity.

\section{CONCLUSIONS}

The Lesser Himalayan metabasites contain almost constant mineral assemblage of Ca-amphiboles, biotite, plagioclase, quartz, epidote, chlorite and $\mathrm{Fe}$ -
Ti oxides. Modal percentage of amphiboles and biotite increases, and that of epidote and chlorite decreases from south (structurally lower part) to north (structurally higher part) towards the Upper MCT in the LH. Amphiboles in the form of porphyroblast are chemically zoned with actinolite cores and hornblende/tschermakite rims showing their twostage metamorphic growth. The actinolite cores are pre-kinematic and were formed most probably prior to the Tertiary Himalayan orogeny. Hornblende forming matrix and rims of porphyroblasts are synkinematic and were formed during shearing along the Upper MCT in the Tertiary. The systematic compositional changes of syn-kinematic amphiboles and textural characteristics confirm the classical concept of increasing metamorphic grade northwards (structurally upwards) in the LH.

\section{ACKNOWLEDGEMENTS}

This work is a part of my post-doctoral research under fellowship from the Japan Society for the Promotion of Science (JSPS) from 2004-2006. I am grateful to Prof. K. Arita for hosting me during the post-doctoral research.

\section{REFERENCES}

Ahmad, T., Mukherjee, P.K. and Trivedi, J.R., 1999. Geochemistry of Precambrian mafic magmatic rocks of the western Himalaya, India: Petrogenetic and tectonic implications. Chemical Geology, v. 160, pp. 103119.

Arita, K., 1983. Origin of the inverted metamorphism of the Lower Himalayas, central Nepal. Tectonophysics, v. 95, pp. 43-60.

Arita, K, Hayashi, D. and Yoshida, M., 1982. Geology and structure of the Pokhara-Piuthan area, central Nepal. Journal of Nepal Geological Society, Special Issue 2, pp. 529.

Blundy, J.D. and Holland, T.J.B., 1990. Calcic amphibole equilibria and a new amphibole-plagioclase geothermometer. Contribution to Minera logy and Petrology, v. 104, pp. 208-224.

Bollinger, L., Avouac, J.-P., Beyssac, O., Catlos, E.J., Harriso,. T.M., Grove, M., Goffé, B. and Sapkota, S., 2004. Thermal structure and exhumation history of the Lesser Himalaya in central Nepal. Tectonics doi:10.1029/2003TC001564.

Bollinger, L. and Jantos, E (2006) Evidence for MioPliocene retrograde monazite in the Lesser Himalaya, far western Nepal. Eur J Mineral, v. 18, pp. 289297

Bouchez J.L and Pêcher, A., 1981. The Himalayan Main 
Central Thrust pile and its quartz rich tectonites in central Nepal. Tectonophysics, v. 78, pp. 23-50.

Brown, E.H., 1977. The crossite content of Ca-amphibole as a guide to pressure of metamorphism. Journal of Petrology, v. 18, 5372.

Brunel, M., 1986. Ductile thrusting in the Himalayas: shear sense criteria and stretching lineations. Tectonics, v. 5, pp. 247-265.

Catlos, E.J., Harrison, T.M., Kohn, M.J., Grove, M., Ryerson, F.J., Manning, C. and Upreti, B.N., 2001. Geochronologic and thermobarometric constraints on the evolution of the Main Central Thrust, central Nepal Himalaya. Journal of Geophysical Research, v. 106, pp. 16177-16204.

Copeland, P., Harrison, T.M., Hodges, K.V., Maruéjol, P., Le Fort, P. and Pêcher, A., 1991. An Early Pliocene disturbance of the Main Central Thrust, central Nepal: implications for Himalayan tectonics. Journal of Geophysical Research, v. 96, pp. 8475-8500.

Dhital, M.R., Paudel, L.P., Shrestha, R., Thapa, P.B., Oli, C.B., Paudel, T.R. and Jaisi, D.P., 1998. Geological map (1:50,000 scale) of the area between Kusma, Syangja and Galyang, western Nepal, Lesser Himalaya. Published by the Central Department of Geology, Tribhuvan University, Kathmandu, Nepal.

Gansser, A., 1964. Geology of the Himalayas. Interscience Publisher, London. 289p

Graham, C.M., 1974. Metabasite amphiboles of the Scottish Dalradian. Contributions to the Mineralogy and Petrology, v. 47, pp.165 185.

Guillot, S., 1999. An overview of the metamorphic evolution in central Nepal. Journal of Asian Earth Sciences, v. 17, pp. 713725.

Holland, T.J.B. and Richardson, S.W., 1979. Amphibole zonation in metabasites as a guide to the evolution of metamorphic conditions. Contributions to the Mineralogy and Petrology, v. 70, pp.143-148.

Johnson, M.R.W. and Oliver, G.J.H., 1990. Precollisional and post collisional thermal events in the Himalaya. Geology, v.18, pp. 753756.

Krummenacher, D., 1966. Népal Central: géochronométrie des series de l'Himalaya. Bull Schweiz Mineral Petrogr Mitteil, v. 46, pp. 43-54.

Krummenacher, D., Basett, A.M., Kingery, F.A. and Layne, H.F., 1978. Petrology, metamorphism and K/Ar age determinations in Eastern Nepal. In: Saklani PS (ed) Tectonic Geology of the Himalaya, Today and Tomorrow's Printers and Publishers, New Delhi.

Le Fort, P., 1975. Himalayas: the collided range, present knowledge of the continental arc. American Journal of
Science, v. 275A, pp. 144.

Liard, J. and Albee, A.L., 1981. Pressure, temperature, and time indicators in mafic schist: their application to reconstructing the polymetamorphic history of Vermont. American Journal of Science, v. 281, pp. 127175.

Miyashiro, A., 1973. Metamorphism and Metamorphic Belts. Allen and Unwin, London

Oliver GHJ, Johnson MRW, Fallick AE (1995) Age of metamorphism in the Lesser Himalaya and the Main Central Thrust zone, Garhwal India: results of illite crystallinity, 40Ar/39Ar fusion and K-Ar studies. Geological Magazine, v. 132, pp. 139149.

Paudel, L.P. and Arita, K., 2000. Tectonic and polymetamorphic history of the Lesser Himalaya in central Nepal. Journal of Asian Earth Science, v. 18, pp. 561584.

Paudel, L.P. and Arita, K., 2006. Thermal evolution of the Lesser Himalaya, central Nepal: Insights from K-white micas compositional variation. Gondwana Research, v. 9, pp. 409425.

Pêcher, A., 1977. Geology of the Nepal Himalaya: deformation and petrography in the Main Central Thrust zone. Ecologie géologie l'Himalaya, CNRS Paris, v. 268, pp. 301318.

Pêcher, A., 1989. The metamorphism in central Himalaya. Journal of Metamorphic Geology, v. 7, pp. 31-41.

Raase, P., 1974. Al and Ti contents of hornblende, indicators of pressure and temperature of regional metamorphism. Contributions to the Mineralogy and Petrology, v. 45, pp. 231236.

Sakai, H., 1985. Geology of the Kali Gandaki supergroup of the Lesser Himalaya in Nepal. Memoirs of the Faculty of Science, Kyushu University (Japan). Series D, Geology, v. XXV, pp. 337397.

Stöcklin, J., 1980. Geology of Nepal and its regional frame. Journal of Geological Society of London, v. 137, pp. 134.

Triboulet, C., Thie'blemont, D. and Audren, C., 1992. The (Na-Ca) amphibole-albite-chlorite-epidote-quartz geothermobarometer in the system S-A-FM-C-N-H2O. 2. Applications to metabasic rocks in different metamorphic settings. Journal of Metamorphic Geology, v. 10, pp. 557566.

Upreti, B.N., 1999. An overview of the stratigraphy and tectonics of the Nepal Himalaya. Journal of Asian Earth Science, v. 17, pp. 577606.

Zenk, M. and Schulz, B., 2004. Zoned Ca-amphiboles and related $\mathrm{P}-\mathrm{T}$ evolution in metabasites from the classical Barrovian metamorphic zones in Scotland. Mineralogical Magazine, v. 68, pp. 769786. 